\title{
An Appraisal of Man's Essence in Bantu Ontology
}

\author{
Celestine Chukwuemeka Mbaegbu \\ Department of Philosophy, Nnamdi Azikiwe University, Awka, Nigeria \\ Email: ezeakilebuchi@gmail.com
}

Received 18 November 2014; accepted 24 March 2015; published 26 March 2015

Copyright (C) 2015 by author and Scientific Research Publishing Inc.

This work is licensed under the Creative Commons Attribution International License (CC BY). http://creativecommons.org/licenses/by/4.0/

(c) (i) Open Access

\begin{abstract}
With the Socratic injunction: "man know thyself"; the West began a formal search for the nature of man. What is man? What is his essence in real life; what exactly makes him what he is? These questions, apart from dividing philosophers in the West into different warring camps, also portray man as incapable of self knowledge; hence man is described as a paradox. This seemingly insoluble problem among Western philosophers is grounded on their conception of reality as static and dichotomised. In Africa with the understanding of reality as one unitary whole, though distinct and yet complementary, penetrating and interacting with each other, the dualism disappears and there is what we call the "harmony of African conceptions". In this article, using comparative analysis, the essence of man is critically examined within a particular African culture, namely, Bantu ontology and with their conception of reality as dynamic, a conception in contradistinction to the Western static conception of reality The conclusion is that a new definition of man emerges, a definition which is one of the essential characteristics of who is an African?
\end{abstract}

\section{Keywords}

Man, Essence, Bantu, Ontology, Bantu Ontology, Being-With

\section{Introduction}

The history of philosophy reveals that the formal anthropological question: What is man is coeval with Greek civilization and philosophy; even though the early Greek philosophers turned their attention primarily to unravelling the cause or causes of the material universe, yet the problem of man's nature was interwoven with that of the universe since man was regarded as part of nature. This fact is well articulated by Okolo (1998: p. 99) when he reiterated in no uncertain terms that:

Man as the object of knowledge has remained a difficult quest practically since the dawn of philosophic re- 
flection. I can't as yet know myself was a straight forward confession of Socrates on the question, following his injunction at Delphi. Philosophers ever since have seriously attempted various ways to attain selfknowledge, in fact to face the most profound and perplexing of all questions, namely, what is man; what is his essence in real life.

One can say therefore that a particular and exclusive study of man began with Socrates when he had to execute a command that was to him categorical and purposeful. In his Meditations on First Philosophy, Descartes (1960: p. 24) who, perhaps, can rightly be regarded as the best known modern philosopher, raised the issue of man with renewed urgency when he posed this sole-searching question: "What then have I previously believed myself to be? Clearly, I believed that I was a man". Indeed the problem of man is not new to philosophers. One negative achievement which this problem had made was splitting the West and the whole philosophic tradition, namely, Western, Indian, American, Asian, etc.; into different warring camps, thus making the problem much more intricate.

However difficult the knowledge of man is, man at least since Socrates, has always had reasons to raise the Cartesian Question anew. For as a historical being, his actions in every culture have always been a mixture of good and bad, of excellence and plain degradation. This contrasting quality of good and evil which characterizes his actions, among other things, has caused him no small embarrassment and wonder as to his true nature, whether indeed he is what Aristotle says he is a beast or a god. It is on the same ground that Russell (1979: p. 70) makes these revealing statements:

Man demands consideration solely as the instrument by means of which we acquire knowledge of the universe $\cdots$ we are not in the mood proper of philosophy so long as we are interested in the world only as it affects human beings; the philosophic spirit demands interest in the world for its own sake. But since we apprehend the world through our senses and think about it with our intellect, the picture that we acquire is inevitably coloured by the personal medium through which it comes to us. Consequently we have to study this medium, namely, ourselves in order to find out, if we can, what elements in our picture of the world are contributed by us and what elements we may accept as representative of outside fact.

This article therefore is an attempt or a critical inquiry into the ideas, the Bantu have about the basic philosophic question: What is man? It is an attempt to join others in raising the problem of man anew in a particular environment, namely, the world of the Bantu. The Bantu concept of man is rooted in their ontology which is white different from Western thought. This is a major contribution to world knowledge from Bantu of Rwanda in Africa. We begin with the question of man's essence in Western philosophy.

It is not the task of this work to go into detail the works of Western philosophers on the question of man's essence. If I were to use Russell's words (1967: p. 14): "It is a large and serious question, and if I were to attempt to deal with it in any adequate manner I should have to keep you here until kingdom come so that you will have to excuse me if I deal with it in a somewhat summary fashion". Consequently our concern is their notion of man in their philosophies in a summary form which will form a background to our further investigation of the concepts of man in Bantu ontology. In the end, that is to say, having studied the essence of man in both cultures, namely, Western and Bantu, we should be able to see the contributions of Western thought to Bantu notions of man and vice-versa. It therefore serves as a kind of introduction to our later analysis of man in Bantu Ontology.

\section{The Question of Man's Essence in Western Philosophy: The Three Broad Camps}

All through the history of philosophy various attempts have been made by philosophers to answer the question of man. The marvels, the complexities of the human person and the combined activities of man, namely the shortness of human life, man's superiority over the rest of nature which he controls and which serve him, his strength and infirmity, his joys and sorrows, accomplishments and failures, his various experiences on the realities of life particularly man's own experience of auto-transcendence have led philosophers to raise anew the problem of man's essence, what is man? What exactly makes man what or who he is?

This basic question of philosophy can be said to have split philosophy and perhaps the whole tradition of the Western thought. But since the human mind presses for categories in things the range and scope of the seemingly opposing camps of philosophers on this problem can be grouped into three, namely, those who advance the theory that man is essentially all soul; in the second camp are those who adhere to all body theory and finally the third camp, the middle-course philosophers, who maintain that man is composed of soul and body. Man accord- 
ing to philosophers in this camp is a unity of some sort. This view is held nearly by all philosophers regardless of their tradition. But how this unity can be explained in the face of complex activities that characterize man as man is another problem all together. It means that it is precisely because of the diverse character of man's activities that an adequate notion of self is difficult and hence controversial. These accords in all respects with the observation which Royce (1961: p. 24) made of the problem about man when he writes: "If man had only one operation he would only be one kind of being. But in view of the complexity of human operations, the unity of man's nature presents a real problem". If man is a paradox, if thinking is not the only operation of man, if he sings, makes tools, creates language, arts and lives in a symbolic universe where language, myth, art and religion are part of this universe as Ernst Cassirer puts it, what then is man?

\subsection{Idealist View: Man as All Soul}

This view owed its origin from the Greeco-Roman world and was borrowed, and revived in a slightly different form during the Renaissance, namely, that man is essentially a rational being or a spiritual being. Plato for instance who took the extremist view in this camp lodges the essence of man in his spirituality with just a loose, independent or united connection to the body. Body and soul are thus seen as two distinct realities, although somehow held together. For Plato, man is the soul entombed in the body as an Oyster in its shell. Man is a soul having a body and it is for the former to rule the latter. Look at it this way, too, [Plato says to Socrates] "when soul and body are in the same place, nature teaches the one to serve and to be the subject and the other to rule and govern".

In St. Augustine, as reviewed by Resse (1980: p. 328), "his study of the human soul compelled him to the study of the two natures of man as: an organism with two parts-the soul and the body" and this lead Hamilton (1969: p. 177) to agree with Augustine that "this composition of man was his basic background for submitting that man belongs to two cities or societies: the city of God and the city of man”. In the city of man, St. Augustine maintains that man is predestined to suffer punishment with the devil. Man's happiness in this city is temporal and limited. The reason for this limitation is due to the punishment for Adam's Original sin.

In St. Augustine, therefore, the ideas of Plato seem to be reflected with due clearness and precision, particularly, since he was once committed to Manichaeism and its religious philosophy of matter as evil. Consequently, there are obvious indications in St. Augustine that matter is ignored and at times overlooked. Man's body is attached to the soul. The real man is the soul.

In modern times, Rene Descartes, a French mathematician and philosopher was the first to liberate philosophic thought from the confines of tradition-bound scholasticism. Hegel and many others have called him the father of modern philosophy, the proponent of a thorough-going dualistic philosophy. Descartes radically distinguished between the mind perceived as indubitable in his famous statement: "I think therefore I am", and the body (or matter in general) for which he was the first to provide a comprehensive explanation on the basis of purely mechanistic principle.

Man is primarily a thinking thing res cogitans since thought or spirit is his essence. He is principally a spirit. The mind for him is completely different and distinct. It is utterly non-spatial without shape, size nor location. The body is the exact opposite, res extensa with shape, size, and location in space. With this conception of man, Descartes, with Plato, St. Augustine, etc.; pursued somewhat similar doctrine of man. For these philosophers also the soul and body have a unity of some kind and this unity is caused by God, that is to say, it is God who unites the soul to the body mechanism.

Descartes in his book Meditations on First Philosophy, a book which justifies him as the founder of modern philosophy poses the soul searching question: What is man? How he is what he is; and how he knows what he is? To be precise the second Meditations are about this problem. Elsewhere Descartes (1955: p. 350) writes: "These men shall be composed as we are of soul and body and I shall describe to you first, also by it and finally I must show you how these natures are to be joined and united to compose men which resemble us".

One thing clear from this description is that man is composed of two entities: body and mind, very distinct and different in nature. Precisely according to Descartes, the body is nothing else than the statue or machine or clay which God forms. For him, man is more than a biological entity, namely: matter or body. A human person is a thing that is or exists. But what is this existing thing? For as often as I think, says Descartes, I know that I exist, for perhaps it would ever happen I should wholly cease to think, that I should at the same time altogether cease to be. Thus a human person is what Descartes calls, "the I that thinks". It is a thing that doubts, wills, af- 
firms, understands, conceives, refuses, judges, etc. Summarily, we describe Descartes view of man as treated above in the words of Gilbert Ryle, revisited by Ogilri (1973: p. 75) when he opines that "with the doubtful exception of idiots and infants-in-arms, every human being has both a body and a mind. Some would prefer to say that every human being has both a body and a mind. His body and his mind are ordinarily harnessed together, but after death of the body his mind may continue to exist and function".

The problem, namely, whether man is distinct from brute beasts attracted the attention of many philosophers. Consequently, such deep thinkers like Aristotle, Aquinas, Leibniz, Spinoza, Locke, Kant, Hegel and so on rank man essentially higher than the animal kingdom. They attributed rationality to man alone. Thus man came to be defined as a rational animal. All other animals, they maintained lack this unique quality of man, no matter how intelligent or sagacious, their instinctive reaction to things and situations are. According to these philosophers, this power which gives man a different metaphysical status, call it reason, intellect, thought, understanding, and so on manifest itself in distinctive human activities: Law-making, works of arts, technological and scientific researches, Logic, formulation of general ideas, etc.

The main course or trail of our reasoning is that an important heritage from Greeco-Roman world, mainly through Plato and Neo-Platonists, is the belief or conception that man is all-soul in other words, basically spiritual. The circle broadens with an additional element to man's essential constitution, the power of choice or freewill.

It is worth mentioning here that despite the existence of an extreme position held by George Berkeley, no upholder of this view interprets all soul, or rational or spiritual, to mean that there is no connection of man with matter.

\subsection{Man as All Matter}

Man as viewed by philosophers in this camp has lost his superior metaphysical status. He is conceived as basically material, just like other material existents. This implies that man differs from other things in the universe in degree only. The proponents of this view are the ancient and modern materialists, the dominant principles of their doctrine being that of atoms or mechanism. The chief and outstanding representatives of this school of philosophers include Democritus and the ancient atomists like Lucritius etc. on the one hand, Hobbes and the eighteenth and nineteenth century materialists such as Holback, Feuerbach etc. on the other hand.

Democritus and his adherents for instance maintain that nothing exists but material atoms and the void. Motion is caused by the interactions of atoms as they vibrate through the void. Man, too, is an aggregate or mass of atoms. Even his most complex behaviour can be reduced to atoms in their various interactions.

It must however be admitted that ,in modern times, the older form of materialism has not enjoyed popular support even among those which, are extreme materialists like Marx, Lenin, Engels and other dialectical materialists as well as non-reductionist naturalists who reject the mechanistic interpretation of man according to the atomists. Concerning man, these materialists like Karl Marx, Thomas Hobbes do not hold that man differs from other animals in degree only (neither, of course, do they maintain a radical difference). They however accept some qualitative difference in kind. For them, man is the only being that has the power of thought and the rational control of the environment through his productive powers. Man like other animals makes use of the things in nature but unlike them he fashions things in new ways to suit his aims and needs. Labour or operation thus becomes the specific difference between man and mere brute beasts. Labour according to Marx transforms man into human being in the real sense of the word. For it has developed his body, enriched his mind, and perfected his intellect. This law of the transformation of quantity into quality gives man his distinct quality. Nevertheless, these dialectical materialists share the same fundamental view of man and other things which are that existence is monistic and that the same principle explains all things namely, matter.

Mention has also to be made that the materialistic approach to man is equally evident but in different forms in today’s naturalistic and positivistic studies of psychology. Man is now explained, and defined in terms of psychological process or of intentional flow of consciousness or still a mere configuration of chemical compounds. In essence, in these studies, man differs from other animals only in his advanced anatomical and physiological complexity and his mere behavioural patterns. Ultimately these physiologists whether structuralists or behaviourists, or gestalts share the same basic view of man as the ancient atomists in that man differs from other things in degree only, not in kind. 


\subsection{Man as an Incarnate Spirit (Man as Body and Soul)}

This view of man is widely accepted with fewer objections. This is born out of experience and common sense because man's basic needs appear to be of mixed nature, namely, those of the soul and of the body or spirit and matter. The aspiration to know the truth, for example, is basic to man as his desire to catch some sleep after a day's labour, or to revitalize his sapped strength with food and drink. Even Kierkegaard who espouses the idea of the only-a-soul-theory, (as far as the concept of man is concerned) adds a timely warning that: no one ought to allow himself to be deceived by the fact that he can walk on two legs. As warranted by experience, therefore, man seems to be essentially of two elements: spirit and matter. This is the common tradition of the Thomistic Aristotelian School, although not exclusive to it.

According to this view, in man as in all material things, there are two fundamental principles of being; matter and form, as Aristotle's hylemorphic doctrine states. In Scholastic philosophy these are known as act and potency. In living things the act or the principle of organization (the form) is the soul. Both, soul and, body or, act and, potency or, spirit and, matter complement each other and constitute essentially one entity. One with the other constitutes essentially one entity. One without the other is metaphysically incomplete.

This view seems to be a synthesis of the other two. It is against the materialistic interpretation of man for it argues that man is more than a fortuitous aggregate of molecules and atoms. In man, even though there are two basic elements yet there is substantially one being. Against the platonic-Augustinian tradition, it maintains that the union of soul with the body is far from being unnatural or a hindrance. Each element is a necessary complement to the other and fundamental to the whole being. The Scholastic philosophers even went beyond Aristotle and the ancients in their interpretation of man. For Aquinas and the School-men, man is not only a rational animal or an incarnate spirit but, above all, a person.

These then are the triadic customary approaches to the nature of man, namely, that he is all-soul, or all-body or an incarnate spirit. Other concepts that have influenced present-day views of man are subsumed under any of these categories. As a matter of fact, different philosophers in vogue today project different aspects of man. Consequently there are the collectivist, pragmatic-naturalistic, the analytic-positivistic and the existentialistphenomenological approaches in the study of man.

Notwithstanding all the illuminations the nature of man from these philosophic views which have indeed served man to a great extent, our understanding of man is far from being adequate. Our knowledge is still very much fragmentary and man remains, if not a complete enigma, definitely, an ever present problem to himself. Man as a puzzle in philosophy includes his faculties and the nature of the habits that uniquely characterize him. In the final analysis, it can, however, be said that philosophers raise issues of agreement and/or disagreement concerning man according to whether or not they think him to be essentially above or below or in-between the animal kingdom. Their common views of doubt and/or certainly on the nature of man make the parts of man equally problematic.

In conclusion one can rightly say that these views of man have their limitations for man not only thinks, or senses, he makes tools, etc. We therefore gather that culture, religion, politics, economics, psychology, physiology etc. are important to philosophers as very important guides to a more adequate understanding of the problem, what is man?

\section{Placide Tempels' Bantu Ontology}

Here we shall analyze briefly the Bantu conception of reality as a key to the understanding of man. Tempels (1959: p. 50) summarizes the life of the collective group of the Bantu of Luanda as revolving around the concept of a unique value-that is "vital force". All that exists in Bantu metaphysics, according to Tempels is this force. This is a great reminder of the concept of being and its importance in Parmenidian, Aristotelian and even Heideggerian philosophies. For these great minds, Parmenides specifically, being is absolute, that is to say, whatever is, simply is. To think is to think of something, to think of being. In the same way, force pervades Bantu ontology. Force in Bantu notion is inseparable from the definition of being. Tempels (1959: pp. 50-51) argues that: "There is no idea among Bantu of being divorced from the idea of force. Without the element force, being cannot be conceived". The concept of force is bound to the concept being even in the most abstract thinking upon the notion of being. Comparing the Western and Bantu notions, Tempels (1959: p. 50) observes that "force is the nature of being, force is being, [and] being is force". Kagame maintains that all beings, all essences, in whatever form it is conceived, can be subsumed under the concept force. Force as a social category encompasses 
all beings from God, down to minerals. There is a constant vital interaction among beings that is to say, forces. Tempels (1959: p. 58) argues that: "this concept of separate beings, of substance which find themselves side by side, entirely independent one for another, is foreign to Bantu thought. Bantu hold that created beings preserve a bond one with another, an intimate ontological relationship, comparable with the causal tie which binds creature and creator". Tempels (1959: p. 60) further argues and insistently too that "all creatures are found in relationship according to the laws of a hierarchy that I shall describe later. Nothing moves in this universe of forces without influencing other forces by its movement. The world of forces is held like a spider's web of which no single thread can be caused to vibrate without shaking the whole network".

For the Bantu there is interaction of force with force. This kind of metaphysical interaction among beings transcends the mechanical, chemical and psychical interactions. In the created force, Tempels (1959: p. 64) observes that the Bantu see a causal action emanating from the very nature of that created force and influencing other forces. One force will weaken or strengthen another. The created universe is centred on man. Tempels (1959: p. 65) therefore concludes that "the present human generation living on earth is the centre of all humanity, including the world of the dead". The lower classes: animal, plant and mineral exist according to Tempels only and by the will of God and their purpose is to increase the vital force of men while they are on earth. These inferior forces serve man and to increase his vital force.

It is therefore right to hold as Tempels does that in Bantu thought as well as in the thinking of other peoples of Africa that man sees himself at the centre of the created universe. Ezeanya (1979: p. 15) says of man that "God has made him the focal point of the universe”. Indeed to highlight, the centrality of man's position in the universe scholars have often likened African cosmic vision to a great pyramid which has God the Supreme Being at the apex and man in the middle. Parrinder's (1976: p. 85) categorization of being (forces) according to their hierarchy runs thus: "At [the] apex was God the Supreme Being on the two sides were the great spiritual powers manifested in gods and powers of magic. In the middle was man under the influence of many different kinds of powers". Man therefore remains the centre of the created order with forces above and below him and he cannot but communicate with them regularly at the call of duties or hours of needs. And in the words of Janheinz Jahn, if there were no human forces all forces would be frozen. There would be no procreation, no change, and no life because man by his words calls things and they are.

Bantu ontology apart from its dynamic character, differs greatly from the static views of many Western philosophers, particularly those who reduce reality to being with individuated, discrete existences or substances existing in themselves and isolated from others. For in Bantu ontology the concept of separate beings of substances, to use a scholastic term which exists side by side, independent of one another, is foreign to Bantu thought.

Likewise Bantu ontology differs from the naturalistic ontology of John Dewey, Sidney Hook, John Randall, and others who admit of only one kind of reality in nature, namely, the visible, the tangible, the verifiable. Nature for the naturalists is strictly monistic, without any bifurcation or radical splits and consequently there is nothing like God, spirits, or soul, if these are taken to mean different kinds of beings from the material and the tangible. Nature is an all inclusive category. Nothing exists outside nature for the naturalists. It is all nature or nothing at all. Hence Randall Jr. (1944: p. 367) vehemently maintains that: “Naturalism is opposed to all dualisms between nature and other realms of beings, to the Greek opposition between nature and art; to medieval contrast of the natural and the supernatural... to the dualism pervading modern thought between nature and man".

Man, God, soul and the spirit world are either naturalized within nature or they are non-existent. These views are poles apart from those of the Bantu as we have seen. The Bantu strictly maintain the existence of both the spirit world and the material physical world, the one distinct from, but interacting and penetrating each other.

Lastly in characterizing Bantu ontology we have to emphasize briefly that unlike the existentialists particularly of a radical type, the Bantu, Africans for that matter, do not regard the universe as merely thrown into being. The universe has a cause with God as the creator. This Supreme Being (Ens Supremum) is he who governs it with his laws through the spirits, the ancestors and the laws of the land. In short, below God the creator as we saw in the hierarchy of forces are other forces and they have forces to the degree they are nearer to him who possesses it in its fullness or highest degree.

\section{Man in Bantu Ontology}

In this section of our work we are interested in the soul-searching question "What is man?” as reflected upon by 
Tempels in the philosophical system known as Bantu Philosophy. Indeed, it is a critical reflection on the nature of man in Bantu Ontology. We therefore ask: What then is man in the context of Bantu theory of forces? What is his real essence in nature; what happens to him at death?

From Tempels (1959: p. 52) we learnt that: It is because all being is force and exists only in that it is force that the category force includes of necessity all beings: "God, men living and departed, animals, plants, minerals. Since being is force, all these beings appear to the Bantu as force". Man is therefore defined as a force. But what is his position among other created forces below him in the hierarchy? Tempels accords him an elevated status. According to Tempels (1959: p. 97) "Man is the supreme force, the most powerful among created beings. He dominates plants, animals and minerals. These lower being existed, by Divine decree, only for the assistance of the higher created beings, man". This position and role of man as depicted by Tempels is in accordance with the position God gave to man among all other created beings inferior to man. Thus in Genesis (1: pp. 26-28)

God said, let us make man in our own image, in the likeness of ourselves, and let them be masters of the fish of the sea, the birds of heaven, the cattle, all the wild beasts and all the reptiles that crawl upon the earth. God created man in the image of himself, in the image of God he created him, male and female he created them. God blessed them, saying to them, be fruitful, multiply, fill the earth and conquer it.

This is the basis on which Tempels (1959: p. 98) assigns to man an enviable status and role in the hierarchy of forces when he asserts that "man is a dominant force among all created visible forces. His force, his life, his fullness of being consists in his participation to a greater extent in the force of God". The African world-view is that the universe is not something discrete but a series of interactions and intercommunications. This mode of grasping reality as a whole also colours his understanding of man. Consequently, Tempels (1959: p. 103) expresses this manner of understanding man in Bantu ontology thus: "Just as Bantu ontology is opposed to European concept of individuated things, existing in themselves, isolated from others, so Bantu psychology cannot conceive of man as an individual, as a force existing by itself and apart from its ontological relationship with other living beings and from its connection with animals or inanimate forces around it".

The consequence is that there are no real individuals, without others, a community or a group. This boils down to the fact that the community is an unavoidable criterion for the existence of the individuals. Mbiti (1969: p. 108) articulates this mode of being among the Africans in his famous phrase: "I am because we are, and since we are, therefore I am". Mboya $(1963$ : pp. 164, 165) also stresses the same notion of man as essentially a social category, a being in community, a man with others. He writes: "Most African tribes have a communal approach to life. A person is an individual only to the extent that he is a member of a clan, a community or a family". Tempels (1959: p. 103) is more inclined to this notion of man as a social being because he is of the view that "the Bantu cannot be a lone-being; it is not a good enough synonym for them to say that he is a social being. No, he feels and knows himself to be vital force, at this very time to be in intimate and personal relationship with other forces acting above him and below him in the hierarchy of forces".

In short, according to Tempels (1959: p. 100), "The living Muntu is in relation of being to being with God, with his clan brethren, with his family and with his descendant. He is in a similar ontological relationship with his patrimony, his land with all that it contains or produces, with all that grows or lives on it”. Man in Bantu ontology is therefore a social being, a community being, a being with others and not a lone being or a lone-ranger.

That man is essentially social in Bantu ontology does not mean of course, a total absence of the notion of individuality. Indeed man in Bantu theory of forces is not merely a being from the outside that is to say, in his relation to other beings, a public self, so to say but also private, discrete, and broken off, an individual self. Man possesses some measure of individual existence. Bantu ontology thus recognizes with Dewey (1925: p. 245) the phases of man, namely, that: "There is the individual that belongs in a continuous system of connected events ... then there is the individual that finds a gap between its destructive bias and the operations of the being through which alone its need can be satisfied. It is broken off, discrete because it is at odds with its surroundings".

Apart from asserting that in Bantu ontology man is a being with others and at the same time unique and cannot be duplicated. The Bantu have many ways of establishing the individuality of the individuals. These include: name, physical appearances particularly tribal marks; a person's voice is also believed to represent his personality and hence the efficacy and the importance of listening to a crowd in order to identify the presence of a person 
in a gathering where it is not possible to come out openly to ask for such a person.

An important, basic concept of man in Bantu ontology is the recognition that true humanity is a relationship with others, and that this relationship exists not only among the living but also among the dead. When Mbiti (1969: p. 2) writes that: "to be human is to belong to the whole community and to do so is to participate in the beliefs, ceremonies, and rituals of his group", he was only agreeing with Tempels in underscoring the idea of togetherness and communality which is the essence of the Bantu and the African's view of humanity. This idea is further emphasized by so many African sayings: A man is a man because of others and, life is when you are together, alone you are an animal. In addition to this basic social dimension of man, there is the individual self who socializes, who forms the unit or basis of the community which gives the individual name and meaning.

As to the origin, subsistence or annihilation of the force, man, Tempels (1959: p. 99) recognizes that:

Man is the result of some evolutionary process which brought him from a lower form of life to a higher one, but is a creation of God. God is regarded by the Bantu as the causative agent, the sustainer of these resultant forces, as being the creation cause. Man is one of these resultant living forces, created, maintained and developed by the vital, creative influences of God.

Arguing further Tempels (1959: p. 57) maintains that "the origin, the subsistence or annihilation of beings or of forces, is expressly and exclusively attributed to God". He did not create man out of already existing material but evoked man out of non-being or out of nothing. Religion therefore, more than anything else, influences the Bantu in their conception of man. Religion dominates the whole life of the Bantu and therefore their conception of man is essentially religious.

One is therefore not mistaken to hold that for the Bantu, the problem of man's creation, subsistence or annihilation is not a serious one. All forces owe their existence to God and only God can cause them to cease to exist, according to Tempels (1959: p. 57).

Those who think that, according to the Bantu, one being can entirely annihilate another, to the point that he or it ceases to exist, conceive a false idea. Doubtless one force that is greater than another can paralyze it, or diminish it, or even cause its operation totally to cease, but for all that the force does not cease to exist. Existence which comes from God cannot be taken from a creature by any created force.

In certain Western writings, for instance, in Plato, man is differentiated into body and soul but in Bantu ontology; the individual self is made up of three principal elements, namely, body, shadow and breath. According to Tempels (1959: p. 54) "this breath is the assumed manifestation, the evident sign of life, though it is mortal and in no way corresponds with what we understand by the soul, especially the soul as subsisting after death when the body with its shadow and its breath will have disappeared". This conception of man as three components has not explained where the man has gone after the body and the soul components have separated. The Bantu in the words of Tempels (1959: pp. 54-55) maintain that: "What lives on after death is not called by the Bantu a term indicating part of the man. I have always heard their elders speak of the 'man himself' or it is the little man who was formally hidden behind the perceptible manifestation of the man or the Muntu which at death has left the living".

As to the position of man among the created universe, Tempels observes that the created universe is centred on man. The present human generation living on earth is the centre of all humanity, including the world of the dead. The inferior forces (animals, plants, minerals) exist according to Tempels only by the will of God and their purpose is to increase the vital force of men while they are on earth.

Talking about death in general, superficially and in regard to the external things of life death does not write a finish to the life of man. In the minds of the Bantu, the dead also live, but theirs is a diminished life with reduced vital energy. But when they consider the inner reality of being, Jahn (1961: p. 108) agrees with the findings of Tempels that among the Bantu "the diseased ancestors have not lost their superior reinforcing influences, and that the dead in general have acquired a greater knowledge of life and of vital force or natural forces. Such deeper knowledge as they have in fact been able to learn concerning vital and natural forces they use only to strengthen the life of man on earth".

The dead in Bantu philosophy are not alive, but they do exist. The continued existence of the dead is expressed by Birago Diop, a Senegambian poet and pencilled down by Jahn (1961: p. 108) as follows: "Those who are dead are never gone: They are there in the thickening shadow. The dead are not under the earth. They are in the tree that rustles. They are in the wood that groans. They are in the water that runs. They are in the water 
that sleeps. They are in the hut. They are in the crowd. The dead are not dead."

And in the words of Tempels (1959: p. 65):

The dead forebear who can no longer maintain active relationship with those on earth is completely dead, as Africans say, that is to say, that this individual vital force, already diminished by disease has reached a zero diminution of energy, which (becomes completely static through lack of faculty to employ its vital influence on behalf of the living*. The spirit of those who met their goal of existence, that is, those who recognized that man is constructed for reproduction, that is put into the world in order to perpetuate himself by reproduction seek to enter into contact with the living and to continue living function upon earth.

This raises the question of the life-after death. If it is generally believed that the dead go on a journey and that death does not end life; and if the Bantu believe that this present life is seen as a preparation for the after-life where the dead continue to live after they have completed this life; and if the dead influences the living descendents, do the Bantu mean that when the soul separates from the body at death, it informs another body for another span of earthly life? Or that the soul of a person informs an animal or tree or its human tenement from the ghost realm. If yes, then the Bantu must be firm believers in the principle of reincarnation or metempsychosis or transmigration of souls. To this problem Tempels maintains a clear position when he writes: "so then when Bantu speak of the dead who return and are reborn, we must not regard them as speaking of metempsychosis in the classical sense that we give to this word". Explaining further, Onyewuenyi (1982: p. 158) as an African philosopher gives a philosophical explanation that really throws more light to the issue thus:

Perhaps the idea can be better expressed by saying that it is not a predetermined human being belonging to the clan who is reborn, but that it is his individuality returning to take part in the life of the clan by means of the vital influences through which the diseased gives clan individualization to the newly-born, to the living fruit of the womb, that is to be born into the clan. This vital influence is preserved throughout the whole existence, since it is inherent in the very existence of the being.

This is the basis for saying that belief in reincarnation is impossible in the framework of Bantu ontology. In most books written by whites even in some written by Africans, Africa is depicted as a firm believer in reincarnation. But, in African [Bantu] belief Idowu (1973: p. 187) argues vehemently that "there is no reincarnation in the classical sense. One can only speak of partial or more precisely apparent reincarnation if the word must be used at all". The African [Bantu] is a firm believer in life after death, that is to say the existence of the individual in an incorporeal yet real form, in a life beyond. Onyewuenyi (1982: p. 165) is of the view that: "The whole fuss about decent burial ceremonies and the so called 'ancestor worship' betrays Africans invincible conviction that the dead exist as individuals in the spirit world".

\section{Concluding Reflections}

We tie up our discussion by answering the question posed by Kant, namely, what is man? In the light of our analysis of Bantu ontology, we agree with Tempels that man is the supreme force, the most powerful among created beings. And because man is depicted as being what he is because of the community of forces above and below him in the ontological hierarchy, he cannot be a lone-ranger but a community being, a being with others. This social dimension of man says Tempels does not swallow up the individual as a distinct self; and does not mean the absence of such social evils as tribalism, nepotism, etc. All we are saying is that such a system created by Bantu conception of man in relation to others is in sharp distinction to the system created by Western culture which paved the way for so much individualism and egotism and personal freedom in the Western world.

Of course the Bantu introduces another variety in philosophy in connection with the composition of man. While Plato and his adherents would want us to believe that man is made up of two elements namely, body and soul, the Bantu, would hold to their opinion that man is composed of three vital elements, "body", "shadow" and "breath". Man conceived as the Supreme force in Bantu philosophy tends to dissolve the dualism in Western philosophy of mind and matter. (Rationalism and Empiricism) The same applies to the basic contradiction in human experience, namely, living and dead. In most Western authors for instance, Descartes and Thomas Aquinas, body-soul relationship becomes a problem since the soul and the body are independent beings. But in Bantu philosophy where the soul and body are no longer independent forces but are forces that intermingle and interpenetrate each other the relationship between the body and soul constitute no problem.

Another important revelation from our critical study of Bantu philosophy in connection with our problem, 
what is man is that man's vital force can increase or decrease any inferior force that is the lower forces such as animals, plants and minerals which serve man and his vital force. The dead are not alive but they exist except those who have missed the goal of their existence that is, if for the whole life of their infinite deathlessness left no heirs behind him to perpetrate them through reproduction. In the analytical expression of Jahn (1961: p. 109) "to leave no living heirs behind him is the worst evil that can befall a man, and there is no cause more terrible to put on a man than to wish to die childless". The same fate is assigned by Tempels (1959: p. 65) to "the dead forebears who can no longer maintain active relationship with those on earth is completely dead ... This is held to be the worst disaster for the dead themselves". This is because everything is concentrated on the precious existence of the living in whom the life that was transmitted to them from their ancestors is carried on. On the other hand death for an ancestor who left behind him some heirs is a glorious death. He dies to live through his vital influence which he continues to transmit to his living standards. This vital influence is what has been mistaken and termed reincarnation in certain circles which, as we have said, is impossible in the light of Bantu ontology. Death does not sign a finish to the life of man. But the dead ancestors who missed the goal of their existence are completely dead. Consequently, death as a destroyer is a Western conception. In Shakespeare's Julius Ceasar death is referred to as “a necessary end that must come when it will”. Some existentialist philosophers of the Western world refer to death as the ultimate situation beyond which man or life ceases to exist. The Bantu as we have seen have no less the same idea of this all-imposing phenomenon. They regard death as a cessation of life or further still a paralysis of all mortal vital activities which gives way for another life in the spirit world. Death is conceived as a gate valve, that is to say, as a means to another life; it is a transition from this mortal life to a place of rest in the land of the spirits.

Man in Bantu ontology is enthroned as the master of all things and he does that through the Nommo, (word) the life force which is water and heat, giving life to everything, penetrating everything, causing everything. Little wonder, Jahn (1961: pp. 126, 127) argues and extol the effective power of the word in Africa in the following well worded words:

Thus for everything that happens in this world, for fertility and drought, for sickness and its cure, for happiness and unhappiness, some Muntu or the other is responsible, whether living man, departed or Orisha.

The soothsayer says where the word that produces the evil originated and the medicine man knows the counter-

word, which is stronger and can prevent the evil or illness. All the practices of magic, so much despised, rest on the practice of the Nommo (word).

One after analysing Bantu ontology cannot but also observe, more or less the harmony which Bantu ontology achieves among all the other disciplines: philosophy, theology, politics, social theory, land law, medicine, psychology, birth and burial, etc.; all find themselves logically concatenated in a system so tight that to subtract one item from the whole is to paralyse the whole. For instance, in Western system of thought, God even might be banished from Greek thought without any harm being done to the logical architecture of it. But this cannot be done in the case of the Bantu. Even in the same Western culture, in modern times God even has no place in scientific thinking. This was impossible to the Bantu because according to them nothing moves in this universe of forces without influencing other forces by its movement. The world of forces is held like a spider's web of which no single thread can be caused to vibrate without shaking the whole network. This conception is why it becomes easier to track down offenders, with the consequent limitation of man's freedom and less opportunity for the development of individual potentialities. And since all creatures are found in relationship according to the laws of hierarchy, definitely, there must be a renowned and protected respect for the forces higher in the rank, status and primogeniture. This explains the reason for the so much respect and honour given to the elders in the Bantu world as well as in the African soil or universe.

We therefore conclude with Tempels by saying that the key to the understanding of man is the recognition of a being or force capable of growth, diminution, a force that exercises direct influence on others. One would say in fairness to Bantu ontology that it has opened up a new phase to a new and better understanding of man by revealing the social dimension of man. But that social nature of man is only one out of the many images of man which we need to arrive at a comprehensive and adequate answer to the question of man's essence. Man's knowledge of himself remains in parts. But among the various elements belonging to various dimensions of culture which determine the essential African, what makes the African who or what he is as a distinct cultural being in a distinct world, or what binds Africans together, what gives them a common soul, so to speak includes: 
this communal structure which thanks to our study of man in Bantu ontology we are able to see existing among the Bantu.

\section{References}

Descartes, R. (1955). Selections: Rapheaton. New York: Charles Scribes.

Descartes, R. (1960). Meditations on First Philosophy. New York: Library Arts.

Dewey, J. (1925). Experience and Nature. Chicago: Dover.

Ezeanya, S. N. (1979). The Contributions of African Traditional Religion to Nation Building. Nigerian Dialogues, 3, 1-17.

Hamilton, E., \& Cairns (nd). Plato: The Collected Dialogues Including the Letters. Bollengen Series, LXXI, 95-120.

Idowu, B. (1973). African Traditional Religion. London: Heinemann.

Jahn, J. (1961). Muntu. New York: Groves.

Mbiti, J. (1969). African Religion and Philosophy. London: Heinemann.

Mboya, T. (1963). Freedom and after. London: Andre Deutsche.

Ogilri, J. A. (1973). Self and World. Harwint: Bruce Jonavich.

Okolo, C. B. (1998). The African Person: A Cultural Definition. Indian Philosophy Quarterly, 14, 90-105.

Onyewuenyi, I. C. (1982). A Philosophical Reappraisal of African Belief in Reincarnation. International Philosophical Quarterly, 22, 150-164.

Parrinder, E. (1976). Monotheism and Polytheism in Africa. Journal of religion in Africa, 3, 70-89.

Randall, J. (1944). Epilogue: The Nature of Naturalism. In H. Karikorian (Ed.), Naturalism and Human Spirit (pp. 350-375). New York: Colombia University.

Resse, W. (1980). Dictionary of Philosophy and Religion (Volume 2). Atlantic Highlands, NJ: Humanities Press.

Royce, M. (1961). Man and His Nature. New York: McGraw Hill.

Russell, B. (1967). Why I Am Not a Christian. London: George Allen and Uwin.

Russell, B. (1979). Outline of Philosophy. London: George Allen and Uwin.

Tempels, P. (1959). Bantu Philosophy. Paris: Presence Afrcaine. 